\title{
Newly Approved Drugs and Future Directions for Multiple Myeloma Treatment
}

\author{
Nishant S Gandhi ${ }^{1,2^{*}}$ \\ ${ }^{1}$ Department of Pharmaceutical Sciences, University of Hawaii, USA \\ ${ }^{2}$ Department of Pharmaceutics and Drug Delivery, University of Mississippi, USA
}

Submission: July 21, 2017; Published: August 01, 2017

"Correspondence Address: Nishant S Gandhi, Translational Drug Delivery Research (TransDDR) Laboratory, Department of Pharmaceutical Sciences, The Daniel K Inouye College of Pharmacy, the University of Hawaii at Hilo, 200 W. Kawili Street, Hilo, Hawaii 96720, USA22 \& Department of Pharmaceutics and Drug Delivery, Research of Institute of Pharmaceutical Sciences, School of Pharmacy, University of Mississippi, University, MS 38677, USA, Email: nishantsgandhi@gmail.com

\begin{abstract}
The treatment of Multiple Myeloma has changed dramatically over the past 5-10 years. Advances in therapy have resulted in a significant improvement of overall survival. New drugs introduced in the last few years include Ixazomib, carfilzomib, pomalidomide, and panobinostat. In addition, monoclonal antibodies such as elotuzumab and daratumumab have been approved for the treatment of melanoma in combination with other drugs. In this review, we outline the recently approved drugs and monoclonal antibodies for the treatment of Multiple Myeloma.
\end{abstract}

\section{Introduction}

Multiple myeloma is a malignant disease of the plasma cells that accounts for approximately $1 \%$ of all cancers and $10 \%$ of hematologic malignancies [1-4]. It is the second most common hematological cancer with annual incidence rates in United States of 4.3 per 100,000 and affecting around 20,000 new patients each year [5]. The suffering from myeloma usually experience certain symptoms including Hypercalcemia, renal failure, Anemia/thrombocytopenia and lytic bone lesions. The patients also usually experience common symptoms such as constipation, nausea or poor appetite, increased thirst, fatigue, pallor and

Table 1: Currently approved drugs for the treatment of MM. lower back pain. In multiple myeloma the haematopoietic cells shifts production mainly to produce more B-cells and increased plasma cells. This increased production results in elevated plasma cells in the bone marrow ( $>10 \%$ ). These plasma cells then produce abnormal amounts of antibodies and light chain only which are called the paraproteins (Figure 1). It is typically characterized by the secretion of high amounts of monoclonal antibodies IgG and IgA detectable in the serum or urine of the patient [6]. This review article focuses on the recently approved drugs and monoclonal antibodies for the treatment of MM (Table 1) (Figure 1).

\begin{tabular}{|c|c|c|c|c|c|}
\hline Approved treatment & Brand name & Indication & Approval date & Sponsor \\
\hline Daratumumab & Darzalex & $\begin{array}{c}\text { MM with three prior } \\
\text { treatments }\end{array}$ & $11-16-16$ & Janssen Biotech & Janssen Biotech \\
\hline $\begin{array}{c}\text { Daratumumab } \\
\text { lenalidomide } \\
\text { (Revlimid) and } \\
\text { dexamethasone }\end{array}$ & $\begin{array}{c}\text { MM with atleast 1 } \\
\text { prior therapy }\end{array}$ & 11-21-16 & POLLUX \\
\hline $\begin{array}{c}\text { Daratumumab+ } \\
\text { bortezomib (Velcade) } \\
\text { and dexamethasone }\end{array}$ & $\begin{array}{c}\text { MM with atleast 1 } \\
\text { prior therapy }\end{array}$ & Janssen Biotech & CASTOR \\
\hline $\begin{array}{c}\text { Daratumumab+ } \\
\text { pomalidomide and } \\
\text { dexamethasone }\end{array}$ & & $06-16-17$ & Genmab & EQUULEUS \\
\hline
\end{tabular}




\section{Cancer Therapy \& Oncology International Journal}

\begin{tabular}{|c|c|c|c|c|c|}
\hline $\begin{array}{c}\text { Ixazomib + } \\
\text { lenalidomide and } \\
\text { dexamethasone }\end{array}$ & Ninlaro & & $11-20-15$ & Millenium & - \\
\hline $\begin{array}{l}\text { Elotuzumab + } \\
\text { lenalidomide and } \\
\text { dexamethasone }\end{array}$ & Empliciti & & $11-30-15$ & Facet & - \\
\hline Panobinostat & Farydak & & $02-23-15$ & Novartis & - \\
\hline $\begin{array}{l}\text { Carfilzomib + } \\
\text { lenalidomide and } \\
\text { dexamethasone }\end{array}$ & Kyprolis & $\begin{array}{l}\text { MM with atleast } 1-3 \\
\text { prior therapy }\end{array}$ & $07-24-15$ & Amgen & ASPIRE \\
\hline $\begin{array}{c}\text { Pomalidomide + } \\
\text { dexamethasone }\end{array}$ & Pomalyst & & 02-08-13 & Celgene & - \\
\hline
\end{tabular}

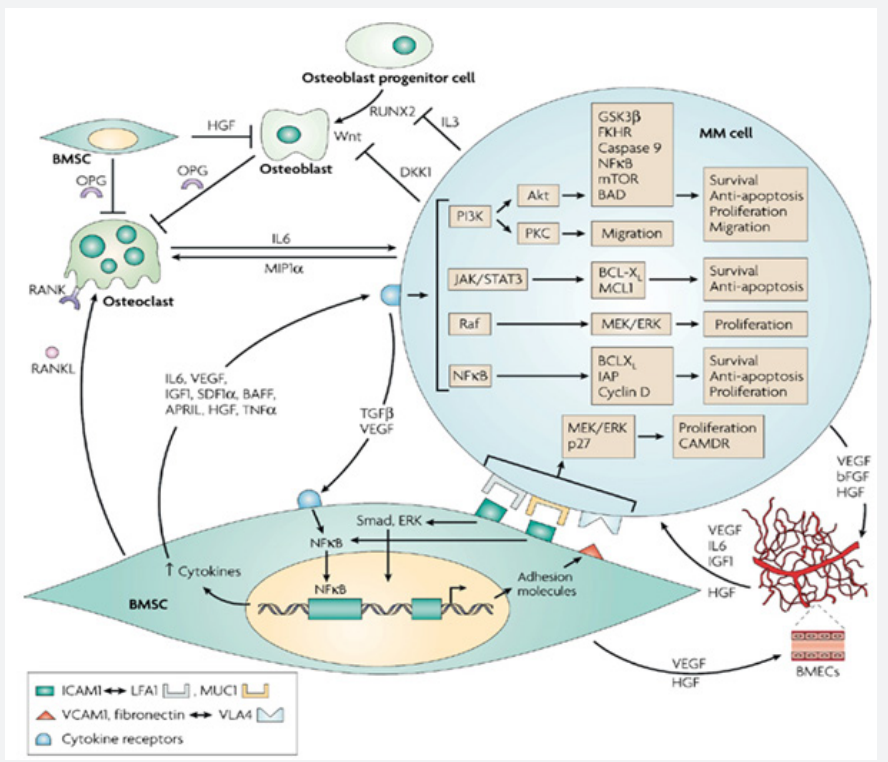

Figure 1: The multiple myeloma (MM) cells adhesion and binding to the bone marrow stromal cells (BMSCs) triggers and up regulates cytokine levels and cytokine mediated tumor cell growth, survival resistance and migration [7].

Currently Approved Treatments for Multiple Myeloma

\section{Daratumumab (Darzalex)}

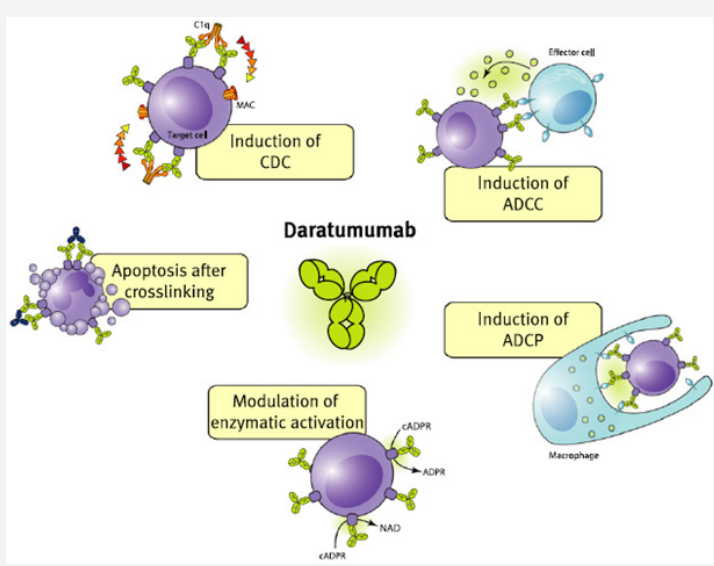

Figure 2: Mechanism of action of Daratumumab. Adapted with permission [8]. The binding of daratumumab to CD38 on the surface of MM cells have been shown to induce ADCC, ADCP tumor cell apoptosis and modulation of the enzymatic activity CD38 [10].
Daratumumab was originally approved by the FDA in November 2015 as a stand-alone treatment for patients who have previously received at least three prior treatments for multiple myeloma [7]. It is a novel high-affinity antibody with a favorable safety profile and a broad spectrum killing activity [2]. Daratumumab is a monoclonal antibody that recognizes a CD38 epitope on the surface of plasma cells or myeloma cells [2]. It allows the cells of the immune system to recognize the cancer cells and destroy the cancer cells in the process (Figure 2).

ADCC - antibody dependent cell cytotoxicity and ADCP antibody dependent cellular phagocytosis. The results from the 12 month randomized trial showed that $83 \%$ of patients in the daratumumab group were alive without disease progression compared to the $60 \%$ in the control group. In addition more patients in the daratumumab group had reductions in the size of their tumors compared to the control group [7]. The FDA has also approved daratumumab (Darzalex) in combination with lenalidomide (Revlimid) and dexamethasone or bortezomib (Velcade) with relapsed myeloma based on the findings of two separate Phase III studies (POLLUX and CASTOR) [8-10]. The 
addition of daratumumab to lenalidomide and dexamethasone reduced the risk of progression or death by $63 \%$ versus the control group (lenalidomide and dexamethasone) in the POLLUX trial. Similarly the addition of daratumumab to bortezomib and dexamethasone reduced the risk of progression or death by $61 \%$ compared to the two drugs alone in the CASTOR trial [11]. The FDA has also recently approved the use of daratumumab in combination with pomalidomide and dexamethasone [12]. The overall response rate in this EQUUELEUS study was 59\%, with very good partial response (VGPR) achieved in $28 \%$ of patients.

\section{Ixazomib (Ninlaro)}

The FDA has approved Ixazomib in combination with Revlimid (lenalidomide) and dexamethasone (a type of corticosteroid) for the treatment of MM who have received at least one prior therapy [13]. Ixazomib is the first oral proteasome inhibitor approved for the treatment of MM [14]. It works by blocking the enzymes from multiple myeloma cells, thus hindering their growth and survival. The addition of Ixazomib to lenalidomide and dexamethasone had longer progression-free survival (PFS) compared to the two drugs alone (20.6 months versus 14.7 months) [14].

\section{Elotuzumab (Empliciti)}

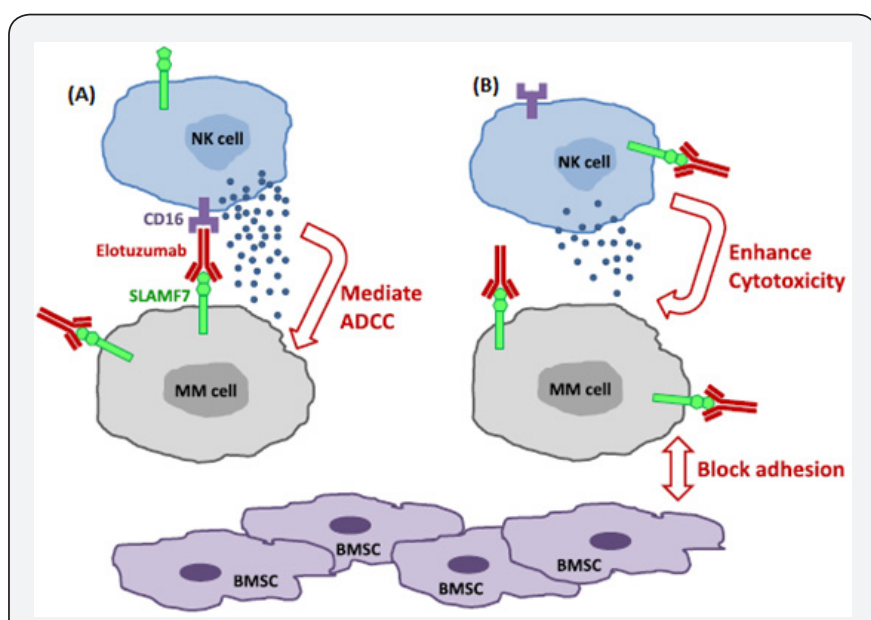

Figure 3: The mechanism of action of elotuzumab.

A. The antibody drug elotuzumab binds to the SLAMF7 receptor on MM cells and its fragment is then bound to other CD16 of the NK cells mediating ADCC.

B. Elotozumab also acts by binding directly to the NK cell, enhancing its cytotoxicity against the MM cells. Further elotuzumab binds SLAMF7 on MM cells, inhibiting its interaction with BMSCs [19].

NK cell natural killer cell; MM cell multiple myeloma cell; BMSC bone marrowstromal cell; ADCC antibody-dependent cellular cytotoxicity

Elotuzumab received the FDA approval in combination with Revlimid (lenalidomide) and dexamethasone to treat patients with myeloma who did not respond to or had relapsed after previous treatment [7]. It is a fully humanized version of MuLuc63 (IgG2a), a mouse monoclonal antibody developed by Hsi and colleagues [15]. It acts by several distinct mechanism including mediating antibody dependent cell-mediated cytotoxicity [15, 16], disrupting MM cell adhesion to the bone marrow stromal cell (BMSC) [16] and enhancing NL cell cytotoxicity $[17,18]$ (Figure 3). Elotuzumab itself doesn't have a single-agent activity. In the randomized clinical trial of 646 , addition of elotuzumab to lenalidomide and dexamethasone resulted in longer PFS compared to the two drugs alone (19.4 months versus 14.9 months) [7].

\section{Panobinostat}

NK cell natural killer cell; MM cell multiple myeloma cell; BMSC bone marrow stromal cell; ADCC antibody-dependent cellular cytotoxicity. Panobinostat (Farydak)-Panobinostat is approved by FDA to be used in combination with bortezomib, and dexamethasone, an anti-inflammatory medication to treat MM in patients who received at least two prior standard therapies [19]. It is the first novel histone deacetylase (HDAC) inhibitor approved for the treatment of MM. Panobinostat exhibited potent inhibitory activity against all class I, II and IV purified HDAC enzymes at low nanomolar concentrations, suggesting their true pan-DAC activity $[20,21]$. The clinical study results showed participants receiving panobinostat in combination with bortezomib and dexamethasone had a disease PFS of about 10.6 months compared to the 5.8 months in participants treated with the two drugs(bortezomib and dexamethasone) alone [19].

\section{Carfilzomib}

Carfilzomib inhibits the chymotrypsin-like site of the proteasome. It is a is a cell-permeable tetra peptide epoxyketone analog of epoxomicin. It primarily inhibits the chymotrypsin-like site of the proteasome [22]. The US FDA approved the drug to be used in combination with lenalidomide and dexamethasone for the treatment of MM in patients who have received 1-3 prior lines of therapy [23]. The patients receiving the 3-drug arm achieved statistically significant prolongation of PFS with median PFS of 26.3 months compared to 17.6 months in 2-drug arm [23].

\section{Pomalidomide (Pomalyst)}

Pomalidomide belongs to the category of immunomodulatory drugs (IMiDs), exerts its anti-cancer effects through several ways, including impeding cytokine production, immunomodulation, and interaction with the bone marrow and tumor microenvironment. The FDA approved pomalidomide in combination with dexamethasone for the treatment of patients with multiple myeloma who have received at least two prior therapies, The patients receiving pomalidomide plus low-dose dexamethasone, demonstrated an overall response rate of 29 percent in comparison to 7 percent in patients treated with pomalidomide alone [24].

Future Directions - Denosumab - Denosumab (AMG162) (Xgeva) is a fully human monoclonal antibody to receptor activator of nuclear factor-nB ligand (RANKL) developed by Amgen to treat patients with skeletal diseases. RANKL plays an 


\section{Cancer Therapy \& Oncology International Journal}

important role in the differentiation and survival of osteoclasts. This results in the establishment and propagation of skeletal disease in patients with MM or bone metastases. Denosumab is developed to treat patients with skeletal diseases is currently in clinical trials and have shown positive clinical results.

\section{References}

1. Rajkumar SV, Kumar S (2016) Multiple Myeloma: Diagnosis and Treatment. Mayo Clinic proceedings 91: 101-119.

2. Phipps C, Chen Y, Gopalakrishnan S, Tan D (2015) Daratumumab and its potential in the treatment of multiple myeloma: overview of the preclinical and clinical development. Ther Adv Hematol 6(3): 120-127.

3. Rajkumar SV, Dimopoulos MA, Palumbo A, Blade J, Merlini G, et al (2014) International Myeloma Working Group updated criteria for the diagnosis of multiple myeloma. The Lancet Oncology 15: e538-e48.

4. Vincent Rajkumar S (2014) Multiple myeloma: 2014 Update on diagnosis, risk-stratification, and management. Am J Hematol 89: 9991009.

5. Kyle RA, Therneau TM, Rajkumar SV, Larson DR, Plevak MF, et al (2004) Incidence of multiple myeloma in Olmsted County, Minnesota: Trend over 6 decades. Cancer 101(11): 2667-274.

6. Rollig C, Knop S, Bornhauser M (2015) Multiple myeloma. Lancet (London, England) 385: 2197-2208.

7. Staff N (2016) Three New Therapies Approved for Multiple Myeloma. NCI, USA.

8. Van de Donk NWCJ, Janmaat ML, Mutis T, Lammerts van Bueren JJ, Ahmadi T, et al. (2016) Monoclonal antibodies targeting CD38 in hematological malignancies and beyond. Immunological Reviews 270: 95-112.

9. Palumbo A, Chanan-Khan A, Weisel K, Nooka AK, Masszi T, et al. (2016) Daratumumab, Bortezomib, and Dexamethasone for Multiple Myeloma. New England Journal of Medicine 375: 754-766.

10. Dimopoulos MA, Oriol A, Nahi H, San-Miguel J, Bahlis NJ, et al. (2016) Daratumumab, Lenalidomide, and Dexamethasone for Multiple Myeloma. New England Journal of Medicine 375: 1319-1331.

11. Broderick JM (2016) FDA Approves Daratumumab Triplets for Relapsed Myeloma. Onclive, USA.
12. Genmab Announces U.S. FDA Approval of Darzalex (daratumumab) in Combination with Pomalidomide and Dexamethasone for Relapsed or Refractory Multiple Myeloma (2017) Nasdaq, USA.

13. FDA approves Ninlaro, new oral medication to treat multiple myeloma (2015) US Food \& Drug Administration, USA.

14. Raedler LA (2016) Ninlaro (Ixazomib): First Oral Proteasome Inhibitor Approved for the Treatment of Patients with Relapsed or Refractory Multiple Myeloma. American Health \& Drug Benefits 9: 102-115.

15. Hsi ED, Steinle R, Balasa B, Szmania S, Draksharapu A, et al. (2008) CS1, a potential new therapeutic antibody target for the treatment of multiple myeloma. Clin Cancer Res 14: 2775-2784.

16. Tai YT, Dillon M, Song W, Leiba M, Li XF, et al. (2008) Anti-CS1 humanized monoclonal antibody HuLuc63 inhibits myeloma cell adhesion and induces antibody-dependent cellular cytotoxicity in the bone marrow milieu. Blood 112: 1329-1337.

17. Wang Y, Sanchez L, Siegel DS, Wang ML (2016) Elotuzumab for the treatment of multiple myeloma. Journal of Hematology \& Oncology 9 : 55.

18. Collins SM, Bakan CE, Swartzel GD, Hofmeister CC, Efebera YA, et al Elotuzumab directly enhances NK cell cytotoxicity against myeloma via CS1 ligation: evidence for augmented NK cell function complementing ADCC. Cancer Immunol Immunother 62: 1841-1849.

19. FDA Approves Farydak (Panobinostat) for the treatment Of Relapsed Multiple Myeloma (2015) The Myeloma Beacon, USA.

20. Atadja P (2009) Development of the pan-DAC inhibitor panobinostat (LBH589): Successes and challenges. Cancer Letters 280: 233-241.

21. Shao W, Growney J, Feng Y, Wang P, Yan-Neale Y, et al. (2008) Potent anticancer activity of a pan-deacetylase inhibitor panobinostat (LBH589) as a single agent in $<$ em $>$ in vitro $</$ em $>$ and $<$ em $>$ in vivo $<$ / em> tumor models. Cancer research 68: 735 .

22. Kortuem KM, Stewart AK (2013) Carfilzomib. Blood 121(6): 893-897.

23. Stewart AK, Rajkumar SV, Dimopoulos MA, Masszi T, Špička I, et al (2015) Carfilzomib, Lenalidomide, and Dexamethasone for Relapsed Multiple Myeloma. New England Journal of Medicine 372: 142-152.

24. Pomalidomide (2013).

\section{Your next submission with Juniper Publishers} will reach you the below assets

- Quality Editorial service

- Swift Peer Review

- Reprints availability

- E-prints Service

- Manuscript Podcast for convenient understanding

- Global attainment for your research

- Manuscript accessibility in different formats

( Pdf, E-pub, Full Text, Audio)

- Unceasing customer service

Track the below URL for one-step submission https://juniperpublishers.com/online-submission.php 